\title{
First Records of Butterflies (Lepidoptera) from the Republic of Nauru ${ }^{1}$
}

\author{
Donald W. Buden ${ }^{2,3}$ and W. Fohn Tennent ${ }^{4}$
}

\begin{abstract}
Four species of butterflies are reported from Nauru for the first time and as first records of butterflies from the island republic. None is endemic. Three of the four species are widespread in Oceania: Badamia exclamationis (Fabricius), Danaeus plexippus (Linnaeus), and Hypolimnas bolina (Linnaeus). The other, Petrelaea tombugensis (Röber), belongs to a genus that also is widespread in the Pacific. The small number of widespread species found on Nauru is comparable with the situation encountered on other small, remote, low-lying Pacific islands.
\end{abstract}

IN THE MOST RECENT checklist of butterflies of Pacific Ocean islands, Tennent (2006) remarked on the absence of records from $\mathrm{Na}$ uru, Midway, and Johnston Atoll among the numerous states, countries, and isolated islands and island groups within this vast area. Froggatt (1910:407) remarked that "butterflies were rare" on Nauru based on information provided by F. W. Steel, who collected insects on Nauru on some earlier but unspecified date. Butterflies seen by Steel were apparently neither identified nor collected. Hambruch (1915) included butterflies (using the German word schmetterling and the Nauruan word ijojimena) in a list of the fauna of Nauru; his accompanying illustration (Hambruch 1915:202, fig. 296) is a poorly rendered generalized diagram of a butterfly unidentifiable as to species. A collection of 41 butterflies recently made by D.W.B. is the basis for this report and the first records of butterflies from the Republic of Nauru.

\footnotetext{
${ }^{1}$ Manuscript accepted 10 October 2007.

2 Corresponding author.

${ }^{3}$ Division of Natural Sciences and Mathematics, College of Micronesia-FSM, P.O. Box 159, Kolonia, Pohnpei, Federated States of Micronesia 96941 (e-mail: don_buden@comfsm.fm).

${ }^{4}$ Department of Entomology, The Natural History Museum, London SW7 5BD, England (e-mail: jtstorment@googlemail.com).
}

Pacific Science (2008), vol. 62, no. 4:495-498

(C) 2008 by University of Hawai'i Press

All rights reserved

\section{Study Area}

The Republic of Nauru $\left(0^{\circ} 30^{\prime} \mathrm{S}, 166^{\circ} 56^{\prime} \mathrm{E}\right)$ consists of a single, small $\left(21 \mathrm{~km}^{2}\right)$, raised atoll island in the west-central Pacific Ocean, approximately $2,100 \mathrm{~km}$ northeast of New Guinea (Figure 1). The nearest island is Banaba (= Ocean) Island, $300 \mathrm{~km}$ to the east. A roughly 100 to $300 \mathrm{~m}$ wide coastal belt abuts a scarp that rises about 30 to $40 \mathrm{~m}$ (maximum elevation $72 \mathrm{~m}$ at Command Ridge) to form the edge of a central plateau. Approximately 10,000 islanders reside on the coastal belt and in a small settlement centered around a brackish lake (Buada Lagoon) in a low-lying area on the southwestern part of the plateau. Coastal vegetation consists largely of strand, scrub, scattered coconut trees, and a variety of ornamentals and fruit trees. Much of the original vegetation of the central plateau was stripped away during a century of opencast phosphate mining, but many of the previously mined areas have since regenerated to scrubland and have small pockets of residual forest dominated by Calophyllum inophyllum (Clusiaceae) and Ficus prolixa (Moraceae). The most extensive remnant forest areas are on the slopes of the scarp and at its base. More detailed descriptions of the physiognomy and vegetation of Nauru are provided by Manner et al. (1984), Thaman (1992), and Thaman et al. (1994).

\section{MATERIALS AND METHODS}

One of us (D.W.B.) visited Nauru during 12-25 December 2006 and 30 March-5 April 2007 to conduct surveys of butterflies, drag- 


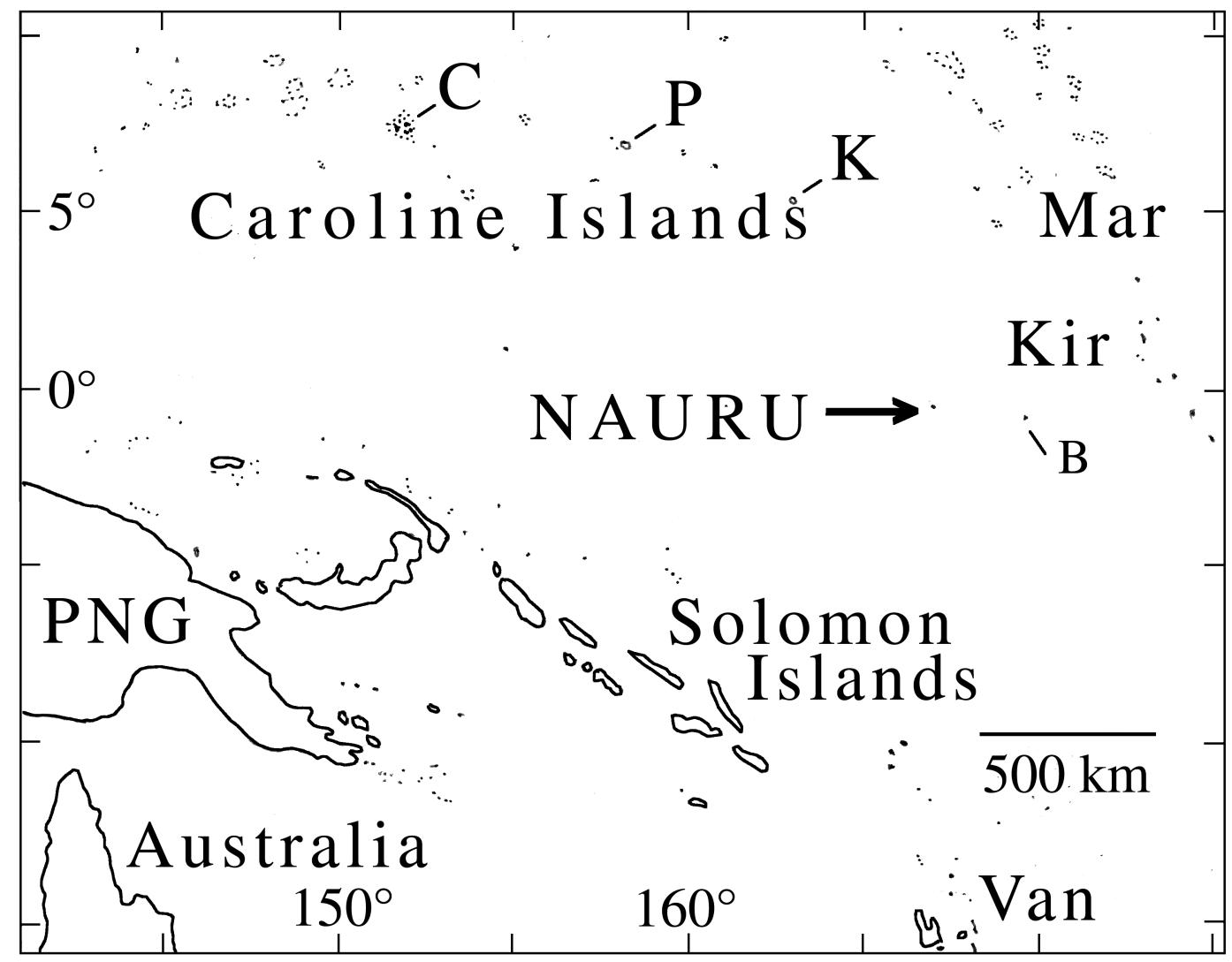

FIgUre 1. Location map for Nauru and surrounding islands: B, Banaba (= Ocean Island); C, Chuuk; K, Kosrae; Kir, Kiribati; Mar, Marshall Islands; P, Pohnpei; PNG, Papua New Guinea; Van, Vanuatu.

onflies, reptiles, and birds. The 41 specimens of butterflies collected during these visits were deposited in The Natural History Museum, London, and, together with personal observations, form the basis for this report.

\section{RESULTS}

Family Hesperiidae

Badamia exclamationis (Fabricius, 1775). one specimen.

A solitary female $B$. exclamationis was collected at the edge of a small grove of $\mathrm{Cal}$ ophyllum inopbyllum trees surrounded by scrubland on the plateau, 31 March 2007; two to three others seen during the MarchApril visit eluded capture. A fast-flying but- terfly glimpsed briefly in scrubland on the central plateau during early evening on 23 December probably was this species.

\section{Family Lycaenidae}

Petrelaea tombugensis (Röber, 1886). 25 specimens.

Although field surveys began on 12 December, this species was not encountered until 16 December, when only one was observed and collected. Others were seen with increasing frequency (up to dozens per day) during the remainder of the December visit, mainly in scrubland on the central plateau. They were often observed two or more in close proximity to each other and usually on or near Premna serratifolia (Verbenaceae) and 
Calophyllum inophyllum. During early April, this species was especially common among shrubs and small trees on the ridgeline at the edge of the central plateau and seemingly attracted to Morinda citrifolia (Rubiaceae), Premna serratifolia, and Colubrina asiatica (Rhamnaceae); several "pairs" were observed in close proximity to each other, flying in tight circles for several seconds before separating and disappearing from view (probably males exhibiting territorial behavior). This species and its congener, $P$. dana (de Nicéville, 1883), are indistinguishable based on external characters. Identity has been confirmed in this case by genitalic examination (cf. Fujioka and Chiba 1998).

\section{Family Nymphalidae} Subfamily Danainae

Danaus plexippus (Linnaeus, 1758). six specimens.

Monarch butterflies were regularly observed along the coastal belt, almost always in close proximity to ornamental shrubs of Calotropis gigantea (Asclepiadaceae), a known host plant, in yards and along roadsides. Three to six D. plexippus were often observed together at a single plant or small group of plants. Solitary specimens were seen infrequently on the central plateau where $C$. gigantea was absent, and they were more common in December than in March/April, when no more than five were observed over a period of a week.

\section{Subfamily Nymphalinae}

Hypolimnas bolina (Linnaeus, 1758). nine specimens.

This species was observed in small numbers (three to four per day) throughout the island during both the December and March/ April visits, and usually in shrubby, weedy, grassy areas.

\section{DISCUSSION}

Only four species of butterflies are recorded from Nauru; none is endemic. Three (Badamia exclamationis, Danaus plexippus, and
Hypolimnas bolina) are widely distributed throughout Oceania and well beyond.

Although the genus Petrelaea is distributed widely in the Indo-Pacific region, it is often overlooked, due in part no doubt to small size, inconspicuous appearance, and a general wariness (Tennent 2002:83). Corbet and Pendlebury (1978:270) reported $P$. dana "males ... not uncommon ... the female is rarely taken" in Malaysia, and Parsons (1998:420) reported P. tombugensis as "generally and locally rare" in Papua New Guinea. Tennent collected P. tombugensis from several of the Solomon Islands in 1996 and 1997 but only saw a small number of males (and no females) during many months in the field (Tennent 2002:83). Several male P. tombugensis collected on islands of Vanuatu in 2002 represented the first records of this species from that island group and a substantial eastward extension of the genus (Tennent 2004); the Nauru records represent the northeasternmost limit of its range. It is interesting that P. tombugensis was the only lycaenid species found on Nauru during this survey, that it was encountered in some numbers, and that specimens included five females. Taking account of a historical extension of taxa from the west, one might expect to find other lycaenid genera (e.g., Jamides Hübner, Nacaduba Moore, or the tiny "grass" blues Zizina Chapman and Zizula Chapman) that occur farther east in the Pacific.

The nine specimens of Hypolimnas bolina collected on Nauru include three males and six females. Females of this species are highly polymorphic (the males much less so), and many female "forms" in the Pacific have been given individual names: see Tennent (2006:181) for additional remarks on these forms. In coloration and pattern, two of the males from Nauru are typical of $H$. bolina throughout its Pacific range, but the third is an unusual form with greatly reduced white markings on the upper surface and an almost unmarked undersurface (i.e., lacking the usual white bands). Of the females from Nauru, all but one are fundamentally f. nerina Fabricius, 1775 , with some minor variation. However, one is of a rather unusual form (except on the Fiji Islands, where it appears to occur fre- 
quently [see Poulton 1924]), in which both surfaces are almost uniformly dark brown, with hardly any trace of the orange or white markings typical of f. nerina. Without exception, the specimens of $H$. bolina collected have torn wings, suggestive of attacks by potential predators, such as birds and lizards.

Additional surveys, particularly at different times of the year, may add to the list of species. However, a meager butterfly fauna such as apparently occurs on Nauru is typical of small, remote, and ecologically impoverished or otherwise faunistically depauperate lowlying islands in the Pacific.

\section{ACKNOWLEDGMENTS}

We are especially grateful to Alamanda Lauti, director of the Nauru campus of the University of the South Pacific, for her considerable assistance with all logistics attending a visit to conduct research in the Republic of Nauru. We also thank Dale Deireragea for assistance in the field and for sharing his knowledge of the island.

\section{Literature Cited}

Corbet, A. S., and H. M. Pendlebury. 1978. The butterflies of the Malay Peninsula, 3rd ed. J. N. Eliot, rev. Malayan Nature Society, Kuala Lumpur.

Froggatt, W. W. 1910. The entomological fauna of Nauru Island, of the Ocean Island group. Proc. Linn. Soc. N.S.W. 35:407410.

Fujioka, T., and H. Chiba. 1988. Notes on the distributions of some Japanese butterflies. Spec. Bull. Lepidopt. Soc. Jpn. 6:141-149.
Hambruch, P. 1915. Nauru. Ergebnisse der Südsee-Expedition 1908-1910. II. Ethnogeographie: B. Mikronesien, Band 1, 2 Halbband. L. Friederichsen and Co., Hamburg.

Manner, H. I., R. R. Thaman, and D. C. Hassall. 1984. Phosphate mining induced vegetation changes on Nauru Island. Ecology 65:1454-1465.

Parsons, M. J. 1998. The butterflies of Papua New Guinea: Their systematics and biology. Academic Press, London.

Poulton, E. B. 1924. Mimicry in the butterflies of Fiji considered in relation to the Euploeine and Danaine invasions of Polynesia and to the female forms of Hypolimnas bolina L. in the Pacific (with an appendix on the numerical aspect of reciprocal mimicry [diaposematic resemblance] by H. H. Turner). Trans. Entomol. Soc. Lond. 1923:564-691.

Tennent, W. J. 2002. Butterflies of the Solomon Islands: Systematics and biogeography. Storm Entomological Publications, England.

- 2004. The butterflies of Vanuatu, with notes on their biogeography (Lepidoptera: Hesperioidea, Papilionoidea). Nachrichten Entomol. Ver. Apollo, N. F. 25:79-96.

. 2006. A checklist of the butterflies of Melanesia, Micronesia, Polynesia and some adjacent areas. Zootaxa 1178:1-209.

Thaman, R. R. 1992. Vegetation of Nauru and the Gilbert Islands: Case studies of poverty, degradation, disturbance, and displacement. Pac. Sci. 46:128-158.

Thaman, R. R., F. R. Fosberg, H. I. Manner, and D. C. Hassall. 1994. The flora of $\mathrm{Na}$ uru. Atoll Res. Bull. 392:1-232. 